\title{
Carotenoid Analysis from Commercial Banana Cultivars (Musa spp.) in Malang, East Java, Indonesia
}

\author{
Jodiawan ${ }^{1}$, Devi Natalia Chrisdiyanti ${ }^{1}$, Nur Vi'atin', Monika Nur Utami Prihastyanti ${ }^{2}$, Rosita Dwi \\ Chandra $^{2}$, Heriyanto ${ }^{1,2,3}$, Chandra Ayu Siswanti ${ }^{2}$, Lia Hapsari ${ }^{4}$, and Tatas Hardo Panintingjati \\ Brotosudarmo $^{1,2^{*}}$
}

${ }^{1}$ Department of Chemistry, Faculty of Science and Technology, Universitas Ma Chung,

Villa Puncak Tidar N-01, Malang 65151, East Java, Indonesia

${ }^{2}$ Ma Chung Research Center for Photosynthetic Pigments (MRCPP), Universitas Ma Chung,

Villa Puncak Tidar N-01, Malang 65151, East Java, Indonesia

${ }^{3}$ Faculty of Biochemistry, Biophysics and Biotechnology, Jagiellonian University, Ul. Gronostajowa 7, 30-387 Krakow, Poland

${ }^{4}$ Purwodadi Botanic Garden, Research Center for Plant Conservation and Botanic Gardens, Indonesian Institute of Sciences (LIPI), Jl. Raya Surabaya - Malang KM. 65, Purwodadi, Pasuruan 67163, East Java, Indonesia

\author{
*Corresponding author: \\ tel: $+62-341-550171$ \\ email: tatas.brotosudarmo@machung.ac.id \\ Received: October 26, 2020 \\ Accepted: January 8, 2021 \\ DOI: $10.22146 /$ ijc. 60865
}

\begin{abstract}
Banana, as the world's most consumed fruit, is a good source of carbohydrate, potassium, fiber, and other essential nutrients such as pro-vitamin A carotenoids. The carotenoid contents and compositions in bananas commonly sold in fruit shops in Malang have become interesting studies. Five types of banana, i.e., Berlin, Mas, Cavendish, Candi, and Raja, were characterized using high-performance liquid chromatography and UV-Vis spectrophotometer. The carotenoid concentrations ranged between 347-3,660 $\mu \mathrm{g} / 100 \mathrm{~g}$ dry weight $(\mathrm{dw})$, with the level of vitamin A activity at the range between 6-139 $\mu \mathrm{g} R A E / 100 \mathrm{~g} \mathrm{dw}$. The Mas banana had a higher carotenoid concentration compared to the Berlin, Candi, Raja, and Cavendish varieties.
\end{abstract}

Keywords: banana; carotenoid concentration; carotenoid identification; Malang; vitamin A activity

\section{- INTRODUCTION}

Carotenoids have been proven as compounds that are able to support biological functions in the human cellular system, such as vitamin A activity, antioxidant functions, and immune system enhancers [1-3]. Nevertheless, several diseases in developing countries related to vitamin A deficiency, cancer, cardiovascular disease, cataracts, and age-related macular degeneration (AMD) are still becoming public attention issues [4]. Due to the inability of cells to biosynthesize carotenoids, humans need diet intake rich in carotenoids to reduce the risk of these chronic illnesses [5]. The main dietary carotenoids generally come from yellow-orange fruits or vegetables, such as bananas which are food commodities that contain carotenoids [6-7].

Globally, people have labeled bananas as the world's fourth staple food after rice, wheat, and maize [8-9]. Interestingly, besides being rich in nutrients and energy, bananas also contain carotenoid pigments, which consist of three main carotenoids: $\alpha$-carotene, $\beta$ carotene, and lutein [10-11]. $\alpha$-Carotene and $\beta$-carotene are pro-vitamin A carotenoids in which each compound can produce one and two retinal molecules in the body [5]. Lutein is a macular carotenoid that can protect the photoreceptor cell of the eye [12]. Consumption of banana flesh could provide supply of pro-vitamin A carotenoids to the human body [7]. 
As a tropical country, Indonesia has considerable potential for the diversity of bananas, which currently there were at least 1,000 cultivars distributed in 16 provinces of banana production centers in Indonesia [13]. Banana production in Indonesia has increased from 6.9 billion tons in 2014 to 7.3 billion tons in 2018, which means the production grew by $5.86 \%$ within 5 years. East Java produced 2.1 billion tons of banana in 2018, increasing $54.11 \%$ from 1.3 billion tons in 2014 , leading to the largest banana production in Indonesia in the same year. Bananas are largely produced in certain regions in East Java, such as Malang, Jember, Lumajang, Bojonegoro, and Pasuruan. In Malang district itself, 32 banana varieties were cultivated by the local communities with a total production of approximately 9,728 tons in 2018, which was the largest production in East Java province [14-16].

The above-mentioned data suggest that an enormous number of bananas have been produced to fulfill consumers' need for a healthy diet. However, people's knowledge on bananas may be limited to Cavendish due to its considerable amount of trade. Food and Agriculture Organization (FAO) claimed that Cavendish dominated $45 \%$ of global production in which 50 billion tons of Cavendish have been globally produced annually. This considerable amount of Cavendish production may be due to its ability to generate high yields and its strength towards environmental issues, such as storms [17]. On the other hand, a lot of banana types have been cultivated in Indonesia other than Cavendish. In fact, 79 cultivars of bananas were found in East Java, moreover, 33 types among them have been cultivated in the Malang region [18]. Recent study on pro-vitamin A carotenoids in local banana cultivar widely grown in Lumajang, East Java, i.e. Agung Semeru banana (Musa paradisiaca $\mathrm{L}$. AAB), revealed that vitamin A activity of it was at $457.33 \pm 5.18 \mu \mathrm{g}$ retinol activity equivalents (RAE)/100 g dry weight ( $\mathrm{dw}$ ) [19]. This fact indicates that local banana cultivars should be taken into consideration as they may have great potential to enhance people's diet of vitamin A.

This enormous amount of local banana cultivars production combined with the content of carotenoids makes bananas as potential fruit source for daily nutrition intake. However, limited information on the total carotenoids of banana cultivars are reported, specifically, those cultivated and commercialized in the Malang region. Therefore, this study aimed to identify, quantify, and evaluate the carotenoid contents of selected bananas cultivated and commercialized in Malang, Indonesia. The selected banana cultivars to be observed were dessert bananas (Berlin, Cavendish, Mas), plantain bananas (Candi) and that which could be served as both (Raja). Identification and quantification of total carotenoids, major carotenoids, and vitamin A activity of five cultivars of banana were carried out by spectrophotometry and chromatographic methods. The information on carotenoid compositions and concentrations as well as vitamin A activity of these bananas obtained in this study may enrich people's knowledge on the function of carotenoid contents of these bananas, thus, leads to a comprehensive understanding on a healthy diet.

\section{- EXPERIMENTAL SECTION}

\section{Materials}

Five cultivars of banana were used in this study, i.e. Berlin (Musa acuminata AA), Mas (M. acuminata AA) and Cavendish (M. acuminata AAA), all of those were classified as dessert bananas, as well as Candi ( $M$. paradisiaca $\mathrm{AAB}$ ) which is classified as plantain, and Raja (M. paradisiaca AAB) which can play role both as dessert and plantain. The whole fruit and half-fruit longitudinal cross-section are depicted in Fig. 1. All the cultivars were purchased from several local markets in Malang, Indonesia. The selected bananas were the ones that had entered ripening stage 6 to 7 , indicated by yellow skin color with several brown spots on the surface area, thus, were ready-to-eat [20]. For analytical purposes, the fresh flesh was taken, immediately sliced, ground using mortar, and stored in the sample tube. These following chemicals, i.e., calcium carbonate $\left(\mathrm{CaCO}_{3}\right)$, ethanol (EtOH), tetrahydrofuran (THF), $n$ hexane, acetone, methyl tert-butyl ether (MTBE), methanol $(\mathrm{MeOH})$, water (Merck), and sodium- $L$ ascorbate (Chameleon), were used for extraction and 


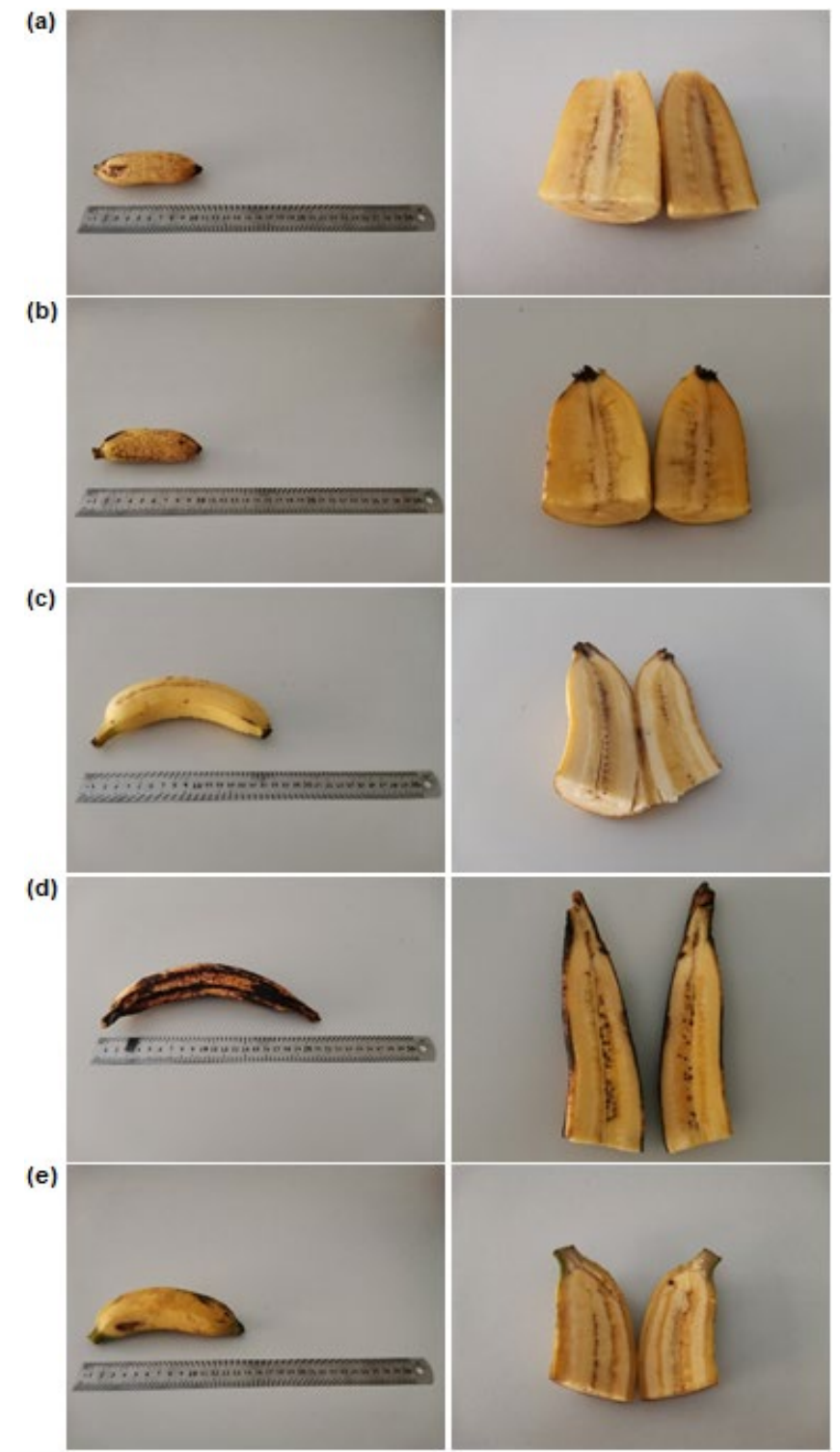

Fig 1. Whole fruit (left) and half-fruit longitudinal crosssection (right) of Berlin (a), Mas (b), Cavendish (c), Candi (d), and Raja (e) bananas

analytical purposes. Lutein, $\alpha$-carotene, and $\beta$-carotene standard pigments ( $\geq 95 \%$ purity level) were obtained from NATChrom (Malang, Indonesia).

\section{Instrumentation}

The absorption spectra of pigment extracts were recorded using a UV-Vis spectrophotometer (UV 1700 Shimadzu). It was also used for the total carotenoids determination of the bananas. High-performance liquid chromatography (HPLC) system (Shimadzu) equipped with a photodiode array detector (LC20A) and column oven (CTO-20A) was used to determine the carotenoid compositions and concentrations of the banana cultivars.

\section{Procedure}

\section{Carotenoid extraction}

Carotenoid extraction was performed based on a previously reported procedure with several modifications $[10,19]$. In a dark room, $3 \mathrm{~g}$ of flesh aliquot were mixed with trace amount of $\mathrm{CaCO}_{3}$ and sodium- $L$ ascorbate, then stirred for $10 \mathrm{~min}$ at $120 \mathrm{rpm}$ in a $10 \mathrm{~mL}$ solvent extraction mixture containing EtOH and THF $(4: 3, \mathrm{v} / \mathrm{v})$. The yellow filtrate containing carotenoids was collected, then the extraction process was repeated four times toward the residue until it became colorless. Furthermore, all carotenoid extracts were combined and transferred in a separatory funnel to be separated from any contaminants by the addition of water and $n$ hexane. The organic layer containing carotenoids was then collected, and the remaining solvent was removed using a rotary evaporator (Heidolph, Schwabach, Germany) at $35{ }^{\circ} \mathrm{C}$. All extraction was performed in duplicate.

\section{Total carotenoids analysis}

The carotenoid extracts in acetone were subjected to UV-Vis spectroscopy measurement (UV-1700, Shimadzu) to record the absorption spectrum and then to determine the total carotenoids. Sample was diluted by 10 prior to the measurement. Total carotenoids (in $\mu \mathrm{g}$ carotenoid/100 g dw) were determined using formulation modified from Gross as follows [21]:

$$
\text { Total Carotenoid }=\frac{\mathrm{A} \times \mathrm{V} \times 10^{6}}{\mathrm{~A}_{1 \mathrm{~cm}}^{1 \%} \times 100 \times \mathrm{G}} \times \frac{100}{100-\text { mositure content }(\%)}
$$

where $A$ represents absorbance at maximum absorption wavelength $\left(\lambda_{\max }\right) ; \mathrm{V}$ is volume of carotenoid extract $(\mathrm{mL}) ; \mathrm{G}$ is weight of sample $(\mathrm{g}) ; \mathrm{A}_{1 \mathrm{~cm}}^{1 \%}$ is specific absorbance extinction of carotenoid mixture in acetone, i.e. $2,500(\mathrm{~mL} /(\mathrm{g} \times \mathrm{cm}))$. Moisture content was measured using a moisture analyser (MOC63u, Shimadzu).

\section{Determination of carotenoid compositions and major carotenoid concentrations}

The carotenoid compositions and major carotenoid concentrations were determined by means of 
HPLC (Shimadzu, Kyoto, Japan), following the method suggested by Kurniawan et al. [22]. The dry carotenoid extract was re-dissolved in $1 \mathrm{~mL}$ of acetone and filtered using a PTFE membrane syringe $(0.22 \mu \mathrm{m}$, Shimadzu), then $20 \mu \mathrm{L}$ of the extract was injected into the reversedphase (RP) HPLC. The separation of pigment was carried out by RP-HPLC using a YMC C30 column $(150 \times 4.6 \mathrm{~mm}$ ID) (YMC, Wilmington, MA, USA), column oven (CTO$20 \mathrm{~A}$ ) at $30^{\circ} \mathrm{C}$, and photo-diode array detector (LC20A). The elution gradient program was regulated by a mixture of $\mathrm{MeOH}, \mathrm{MTBE}$, and $\mathrm{H}_{2} \mathrm{O}(81: 15: 4, \mathrm{v} / \mathrm{v} / \mathrm{v})$ at $0 \mathrm{~min}$ to $(6: 90: 4, \mathrm{v} / \mathrm{v} / \mathrm{v})$ at $70 \mathrm{~min}$ at $30{ }^{\circ} \mathrm{C}$ with a flow rate of $1 \mathrm{~mL} / \mathrm{min}$.

Carotenoid identification was performed based on chromatography result of lutein, $\alpha$-carotene, and $\beta$ carotene standard pigments from a previously described report by Chandra et al. [19]. The lutein, $\alpha$-carotene, and $\beta$-carotene standard pigments in the chromatogram were eluted at $8.3 \mathrm{~min}, 23.5 \mathrm{~min}$, and $26.4 \mathrm{~min}$, respectively. The absorption spectrum properties of peaks (shape or pattern and $\lambda_{\max }$ ) from the banana samples obtained at the same retention time $\left(t_{R}\right)$ were compared with those of standard pigments to confirm pigments identification.

Peak area of major carotenoids at $\lambda_{\max }$ of each banana cultivars obtained from HPLC was used to calculate the concentration of lutein, $\alpha$-carotene, and $\beta$ carotene (in $\mu \mathrm{g} / 100 \mathrm{~g} \mathrm{dw}$ ) by using standard linear equations developed by Chandra et al. [19] and Kurniawan et al. [22], i.e.:

Lutein $: y=305.8 x-0.6335, R^{2}=0.9999$

$\alpha$-carotene $: y=232.04 x-47.906, \mathrm{R}^{2}=0.9950$

$\beta$-carotene $: y=206.57 x-74.953, R^{2}=0.9982$

where $\mathrm{y}$ and $\mathrm{x}$ are peak area $\left(\times 10^{-3}\right)$ at $\lambda_{\max }$ and concentration of measured pigment $(\mu \mathrm{g} / \mathrm{mL})$, respectively.

\section{Vitamin A activity}

Vitamin A activity was described based on concentrations of $\alpha$-carotene and $\beta$-carotene, both are known as pro-vitamin A carotenoids. The concentration of pro-vitamin A carotenoids was converted into retinol activity equivalent (RAE) using a conversion factor of 24:1 for $\alpha$-carotene and 12:1 for $\beta$-carotene.

\section{Statistical analysis}

All values were performed as means \pm standard deviation (SD) of two replicates. Statistical analysis of total carotenoids, lutein, $\alpha$-carotene, and $\beta$-carotene concentrations, and vitamin A activity was performed using one-way analysis of variance (ANOVA). When a significant difference was found, Tukey's Honest Significant Difference test was performed in Minitab software version 17 (Minitab. State College, PA, USA) with 95\% confidence level $(p<0.05)$.

\section{- RESULTS AND DISCUSSION}

The initial study of yellow pigment from five banana cultivars was carried out based on spectroscopic analysis by comparing the total carotenoids of each flesh crude extract. Fig. 2 shows the absorption spectra of crude carotenoid extracts from each sample in $1 \mathrm{~g}$ of $\mathrm{dw}$ basis, where the absorbance value at $\lambda_{\max }$ represents the total value of the carotenoid. Based on the absorbance height of each banana cultivar in Fig. 2, ones can observe that the banana cultivars showed a different concentration of carotenoid. For instance, having the highest absorbance

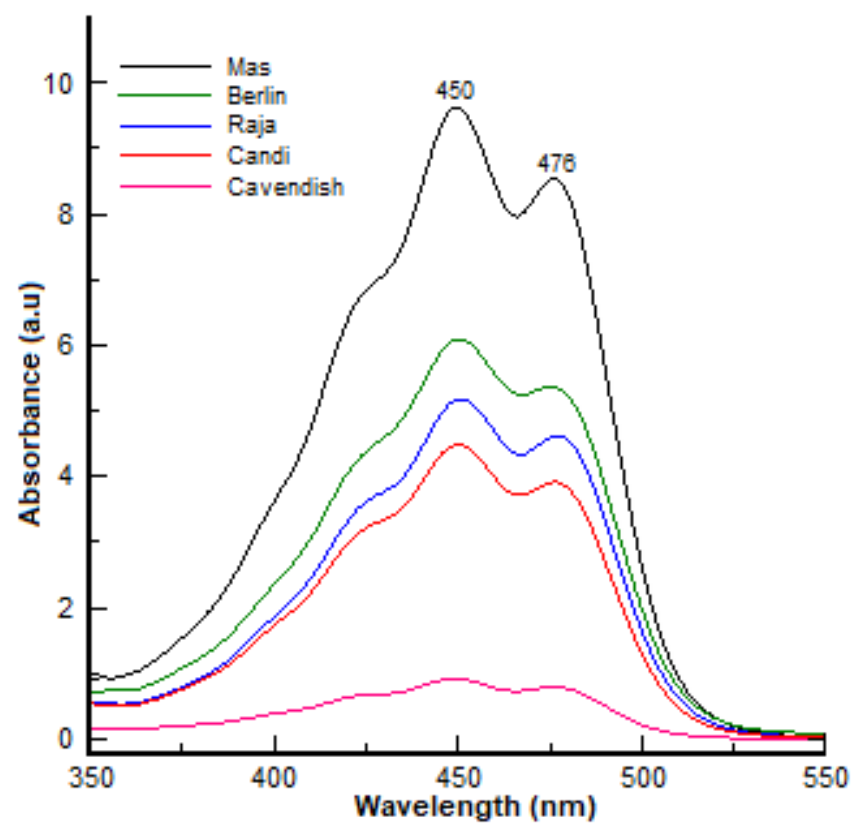

Fig 2. Absorption spectra of carotenoid crude extracts from Mas (black line), Berlin (green line), Raja (blue line), Candi (red line), and Cavendish (magenta line). All extracts were dissolved in $1 \mathrm{~mL}$ of acetone and calculated in $1 \mathrm{~g}$ dw basis 
value, Mas banana would have the highest carotenoid concentration. On the other hand, Cavendish was most likely exhibiting the lowest carotenoid concentration based on its extremely low intensity. Moreover, all samples provided the same $\lambda_{\max }$ and shoulder peak at 450 $\mathrm{nm}$ and $476 \mathrm{~nm}$, respectively. This suggests that the major carotenoid compositions and concentrations will be further discussed.

The banana flesh color indicates the carotenoid contents as can be observed from Fig. 1. For instance, Mas banana exhibited the most intensive orange color among the five banana cultivars, whereas Cavendish showed the least intensive yellow. The difference in flesh color among the cultivars suggests that the carotenoid contents were also varied. One can roughly conclude that Mas banana would have the highest carotenoid content, while Cavendish showed the least. Table 1 shows the total carotenoids in the five banana cultivars which suggests that Mas bananas contained the highest total carotenoids compared to the other four cultivars with $3,660 \mu \mathrm{g} / 100 \mathrm{~g}$ $\mathrm{dw}$. On the contrary, Cavendish shows the least carotenoid among others with only $347 \mu \mathrm{g} / 100 \mathrm{~g} \mathrm{dw}$. The value in Table 1 corresponds to the absorbance value of the bananas shown in Fig. 2. Higher absorbance value indicates higher concentration of carotenoid in the bananas. The result of the ANOVA statistical test suggests significant differences among cultivars, with $p$ values of $0.00(p<0.05)$. Tukey's multiple comparisons confirmed that the total carotenoids in each sample were significantly different from one another, nevertheless, Raja was not significantly different from Berlin and Candi. According to the recommendation for the prevention of cancer and other chronic diseases from the National Academy of Sciences which recommends carotenoid consumption in the range of 9 to $18 \mathrm{mg} /$ day [23], the human carotenoid requirement could be then fulfilled properly with consumption of 300 to $600 \mathrm{~g}$ of Mas banana.

Analysis of total carotenoids describes the total concentration of all carotenoid compounds contained in the bananas. Moreover, to understand the carotenoid compositions and contents, HPLC analysis was performed. HPLC chromatogram of pigment compositions is shown in Fig. 3 which reveals peaks of three major carotenoids possessed by the bananas, i.e. lutein, $\alpha$-carotene, and $\beta$-carotene. The identification of the major carotenoid compounds was based on the spectra shape, $\lambda_{\max }$, and retention time $\left(\mathrm{t}_{\mathrm{R}}\right)$ in the standard pigment chromatogram described in the previous study by Chandra et al. [19]. Peak\#1 was identified as lutein,

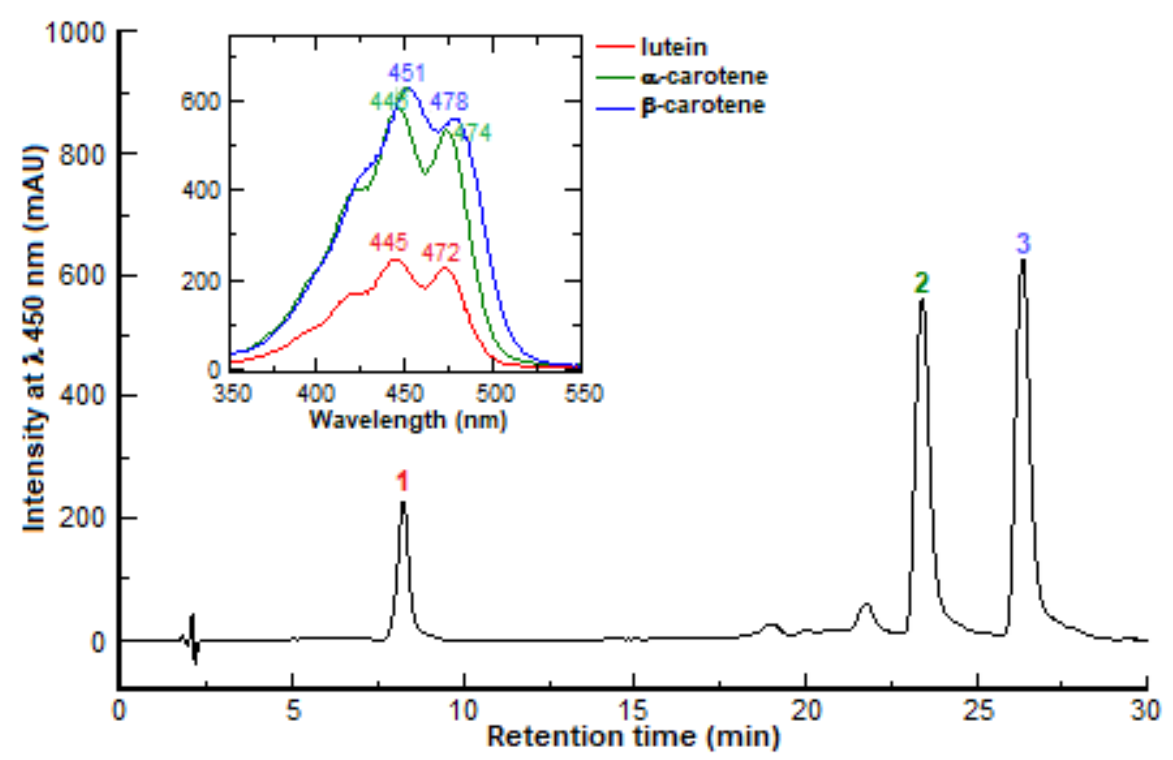

Fig 3. HPLC chromatogram detected at $450 \mathrm{~nm}$ of carotenoid crude extracts from Candi bananas. The intensity was calculated in $1 \mathrm{~g} \mathrm{dw}$ basis. Inset: absorption spectra of lutein (red line, peak \#1), a-carotene (green line, peak \#2), and $\beta$-carotene (blue line, peak \#3) in HPLC eluent 
with $\lambda_{\operatorname{maxs}}$ at 445 and $472 \mathrm{~nm}$, and eluted at min 8.4. Peak $\# 2$ corresponds to $\alpha$-carotene due to its absorption at 446 and $474 \mathrm{~nm}$ and detected at min 23.4. Peak \#3 was eluted at min 26.3 having $\lambda_{\max }$ at 451 and $478 \mathrm{~nm}$, thus, identified as $\beta$-carotene. Previous studies also reported these compounds as major carotenoids in other banana cultivars in several regions in the world, such as in Australia, Africa, and Asia [10,24-27].

Table 1 and Fig. 4 show that each cultivar exhibited different trends in its carotenoid concentration. Raja contained $\beta$-carotene in a higher concentration than $\alpha$ carotene and lutein. Candi and Berlin seemed to follow the same pattern as Raja, however, only a slight difference was found in the concentration of $\alpha$-carotene and $\beta$ carotene between those two cultivars. On the other hand, Mas banana contained $\alpha$-carotene 1.7 and 6.0 times higher than $\beta$-carotene and lutein. Meanwhile, the amount of lutein in Mas, Berlin, Raja, and Candi was relatively low. Compared to $\alpha$-carotene and $\beta$-carotene, the amount of lutein in Mas bananas was 6.0 and 3.5 times lower. In Raja, lutein was found 4.7 and 5.8 times lower than $\alpha$-carotene and $\beta$-carotene. Much lower concentration of lutein was also found in Candi, in which lutein was 10.6 and 10.9 times lower than $\alpha$ carotene and $\beta$-carotene, and in Berlin, where lutein was 12.8 and 13.0 times lower than $\alpha$-carotene and $\beta$ carotene. Interestingly, Cavendish bananas were known to produce lutein in a greater quantity than the other two compounds, covering approximately $50 \%$ of the whole major carotenoid.

Furthermore, the concentration of the major pigments varied among all cultivars. Mas bananas showed the highest content of lutein, i.e. $258.65 \mu \mathrm{g} / 100$ $\mathrm{g} \mathrm{dw}$, followed by Raja, Cavendish, Berlin, and Candi bananas. Concentration of $\alpha$-carotene remains the highest in Mas bananas, followed by Berlin, Raja, Candi, and Cavendish bananas. On the other hand, Raja bananas showed a great amount of $\beta$-carotene among other cultivars, followed by Mas, Berlin, Candi, and Cavendish bananas. Table 1 shows that the concentration

Table 1. Concentration of total carotenoids and major carotenoids from five banana cultivars

\begin{tabular}{lcccc}
\hline \multirow{2}{*}{ Banana cultivars } & \multicolumn{4}{c}{ Concentration $(\mu \mathrm{g} / 100 \mathrm{~g} \mathrm{dw} \pm \mathrm{SD})$} \\
\cline { 2 - 5 } & Total carotenoids & Lutein & $\alpha$-carotene & $\beta$-carotene \\
\hline Mas & $3,669.59 \pm 485.28^{\mathrm{a}}$ & $258.65 \pm 35.80^{\mathrm{a}}$ & $1,556.22 \pm 9.75^{\mathrm{a}}$ & $900.69 \pm 73.57^{\mathrm{ab}}$ \\
Berlin & $2,554.14 \pm 210.56^{\mathrm{b}}$ & $67.81 \pm 4.94^{\mathrm{c}}$ & $870.89 \pm 1.62^{\mathrm{b}}$ & $884.69 \pm 54.70^{\mathrm{ab}}$ \\
Raja & $2,089.60 \pm 206.29^{\mathrm{bc}}$ & $170.54 \pm 34.05^{\mathrm{ab}}$ & $806.26 \pm 5.03^{\mathrm{c}}$ & $983.85 \pm 10.30^{\mathrm{a}}$ \\
Candi & $1,777.77 \pm 278.80^{\mathrm{c}}$ & $64.38 \pm 4.71^{\mathrm{c}}$ & $682.00 \pm 14.93^{\mathrm{d}}$ & $699.44 \pm 19.56^{\mathrm{b}}$ \\
Cavendish & $347.79 \pm 23.45^{\mathrm{d}}$ & $97.43 \pm 1.17^{\mathrm{bc}}$ & $59.43 \pm 1.58^{\mathrm{e}}$ & $41.47 \pm 2.24^{\mathrm{c}}$ \\
\hline
\end{tabular}

${ }^{*}$ values with different alphabet superscripts are significantly different at $p<0.05$

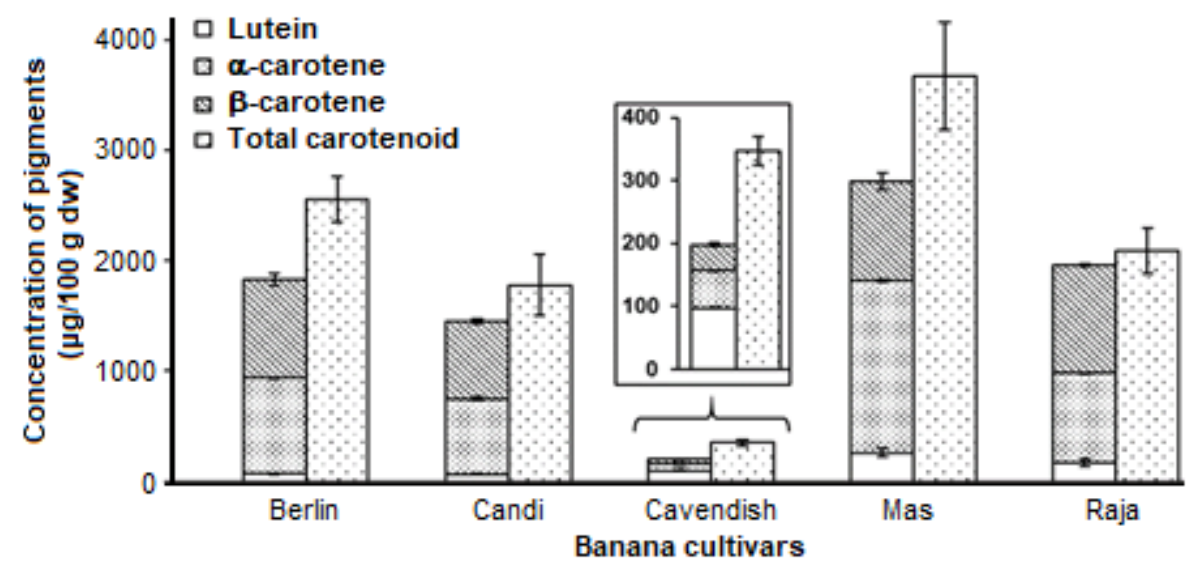

Fig 4. Comparison of major carotenoids (lutein, $\alpha$-carotene, $\beta$-carotene) and total carotenoids $(\mu \mathrm{g} / 100 \mathrm{~g} d \mathrm{~d} \pm \mathrm{SD}$ ) from five banana cultivars. Composition and concentration of major carotenoids were obtained from HPLC analysis, while total carotenoids were derived from spectrophotometry data 
of $\alpha$-carotene in Mas bananas and $\beta$-carotene in Raja bananas were $1,556.22 \mu \mathrm{g} / 100 \mathrm{~g} \mathrm{dw}$ and $983.83 \mu \mathrm{g} / 100 \mathrm{~g} \mathrm{dw}$, respectively. Being the most marketable banana cultivar, Cavendish shows a low amount of $\beta$-carotene which corresponds to previous reports suggesting that Cavendish contained 21 to $290 \mu \mathrm{g} / 100 \mathrm{~g}$ dw of $\beta$-carotene $[7,24,28]$.

Table 1 shows that $\alpha$-carotene concentrations were significantly different among the five banana cultivars, observed from the different letter as the result of statistical test calculation. In terms of $\beta$-carotene concentration, Raja, Candi, and Cavendish were distinguished over each other. Mas and Berlin showed no significant difference, however, they were significantly different from Cavendish. Moreover, lutein content among Berlin, Candi, and Cavendish could be considered not significantly different. Raja and Cavendish showed the same result as well as Mas and Raja. However, Mas showed a significant difference towards Berlin, Candi, and Cavendish.

In addition, a comparison between concentrations of three major pigments and total carotenoids is presented in Fig. 4, showing that the total carotenoids were greater than total concentrations of $\alpha$-carotene, $\beta$-carotene, and lutein. This result implies that more carotenoid compounds existed in the bananas, such as $5,8,5^{\prime}, 6^{\prime}$ diepoxy- $\alpha$-carotene or $5,6,5^{\prime}, 8^{\prime}$-diepoxy- $\alpha$-carotene, 13 cis- $\alpha$-carotene, 15-cis- $\alpha$-carotene, 5,8-epoxy- $\alpha$-carotene, 13-cis- $\beta$-carotene, 9-cis- $\alpha$-carotene or 9'-cis- $\alpha$-carotene and 9 -cis- $\beta$-carotene. Other carotenoid compounds that belong to the xanthophyll group also contribute to the total carotenoids. However, they could hardly be found in the HPLC chromatogram due to an extremely low amount [7,29-31].

The amount of vitamin A activity in the banana cultivars was calculated from the total of $1 / 24$ of $\alpha$ carotene concentration and $1 / 12$ of $\beta$-carotene concentration. Table 2 provides the result of vitamin A activity calculation from five samples in the range from between $5.92 \pm 0.12 \mu \mathrm{g} \mathrm{RAE} / 100 \mathrm{~g} \mathrm{dw}$ and $139.90 \pm$ $6.54 \mu \mathrm{g} \mathrm{RAE} / 100 \mathrm{~g}$ dw. Through Table 2, it can be seen that there were significant differences between cultivars $(p<0.05)$ and there were four groups regarding Tukey's multiple comparison. Berlin and Raja, however, show no
Table 2. Vitamin A activity from five banana cultivars

\begin{tabular}{lcl}
\hline Banana cultivars & $\begin{array}{c}\text { Vitamin A activity } \\
(\mu \mathrm{g} \text { RAE } / 100 \mathrm{~g} \mathrm{dw} \pm \mathrm{SD})\end{array}$ \\
\hline Mas & $139.90 \pm 6.54^{\mathrm{a}}$ & $113.63 \pm 7.08^{\mathrm{b}}$ \\
Berlin & $115.58 \pm 1.07^{\mathrm{b}}$ & \\
Raja & $84.23 \pm 9.98^{\mathrm{c}}$ & \\
Candi & $5.93 \pm 0.12^{\mathrm{d}}$ & \\
Cavendish & & \\
${ }^{*}$ values with different & alphabet superscripts & are \\
significantly different at $p<0.05$ &
\end{tabular}

significant difference. The concentration of $\alpha$-carotene and $\beta$-carotene (Table 2) contribute to vitamin A activity. Therefore, Mas bananas contained the highest vitamin A activity among the other cultivars, while Cavendish became the lowest. Institute of Medicine (U.S) suggested the recommended dietary intake (RDI) values for vitamin A for females and males, $700 \mu \mathrm{g}$ RAE and $900 \mu \mathrm{g}$ RAE, respectively [32]. This means that to fulfill the dietary intake of vitamin A from these five banana cultivars, a considerable amount is needed. This number would be much greater for bananas with a very low amount of vitamin A, such as Cavendish.

\section{- CONCLUSION}

Observational studies on the five banana cultivars in Malang were conducted to analyze the total carotenoids and to identify the dominant carotenoid pigments, i.e. lutein, $\alpha$-carotene, and $\beta$-carotene, as well as to determine their concentration. Each cultivar provided a different amount of major carotenoids. In addition, Mas bananas were found to contain the highest total carotenoids, i.e. $3,669 \pm 485.28 \mu \mathrm{g} / 100 \mathrm{~g} \mathrm{dw}$. These bananas also presented the highest content of lutein and $\alpha$-carotene, while Raja bananas were known to have the highest $\beta$-carotene among other cultivars. On the other hand, Cavendish bananas, although they showed to provide the lowest amount of carotenoid, lutein was found in a higher amount than $\alpha$-carotene and $\beta$ carotene. Moreover, Mas banana exhibited the highest amount of vitamin A activity (139.90 $\pm 6.54 \mu \mathrm{g}$ RAE/100 $\mathrm{g} \mathrm{dw}$ ), suggesting a considerable amount of the bananas to fulfill the dietary intake of vitamin A. 


\section{- ACKNOWLEDGMENTS}

This study was supported by the Indonesian Ministry of Research, Technology, and Higher Education through the National Strategic Excellent Research (PUSNAS) Grant (No.: 120/SP2H/LT/DRPM/IV/2017) and Ministry of Research and Technology/National Agency for Research and Innovation and Indonesia Endowment Fund for Education through Covid-19 research and innovation funding program (No.: 8/FI/PKCOVID-19.2B3/IX/2020).

\section{- AUTHOR CONTRIBUTIONS}

J conducted the experiment, data analysis and wrote the manuscripts. DVC and NV conducted the experiment. MNUP conducted supervision, wrote and revise the manuscript. RDC performed supervision, data analysis, and revised the manuscript. CAS conducted experiment supervision. $\mathrm{H}$ performed supervision and revised the manuscript. LH provided literature review and consultation. THPB conducted supervision. All author agreed to the final version of this manuscript.

\section{- REFERENCES}

[1] Yadav, A., Kumari, R., Yadav, A., Mishra, J.P., Srivatva, S., and Prabha, S., 2016, Antioxidants and its function in human body - A review, Res. Environ. Life Sci., 9 (11), 1328-1331.

[2] Melendez-Martinez, A.J., 2019, An overview of carotenoids, apocarotenoids, and vitamin A in agrofood, nutrition, health, and disease, Mol. Nutr. Food Res., 63 (15), 1801045.

[3] Miller, A.P., Coronel, J., and Amengual, J., 2020, The role of $\beta$-carotene and vitamin $A$ in atherogenesis: Evidences from preclinical and clinical studies, Biochim. Biophys. Acta, Mol. Cell Biol. Lipids, 1865 (11), 158635.

[4] Sommer, A., and Vyas, K.S., 2012, A global clinical view on vitamin A carotenoids, Am. J. Clin. Nutr., 96 (5), 1204S-1206S.

[5] Lietz, G., Oxley, A., Boesch-Saadatmandi, C., and Kobayashi, D., 2012, Importance of $\beta, \beta$-carotene 15,15 '-monooxygenase 1 (BCMO1) and $\beta, \beta$-carotene 9',10'-dioxygenase $2(\mathrm{BCDO} 2)$ in nutrition and health,
Mol. Nutr. Food Res., 56 (2), 241-250.

[6] Yuan, H., Zhang, J., Nageswaran, D., and Li, L., 2015, Carotenoid metabolism and regulation in horticultural crops, Hortic. Res., 2, 15036.

[7] Heng, Z., Sheng, O., Yan, S., Lu, H., Motorykin, I., Gao, H., Li, C., Yang, Q., Hu, C., Kuang, R., Bi, F., Dou, T., Xie, S., Deng, G., and Yi, G., 2017, Carotenoid profiling in the peel and pulp of 36 selected Musa varieties, Food Sci. Technol. Res., 23 (4), 603-611.

[8] Lokesh, V., Divya, P., Puthusseri, B., Manjunatha, G., and Neelwarne, B., 2014, Profiles of carotenoids during post-climacteric ripening of some important cultivars of banana and development of a dry product from a high carotenoid yielding variety, LWT-Food Sci. Technol., 55 (1), 59-66.

[9] Amah, D., van Biljon, A., Brown, A., PerkinsVeazie, P., Swennen, R., and Labuschagne, M., 2019, Recent advances in banana (Musa spp.) biofortification to alleviate vitamin A deficiency, Crit. Rev. Food Sci. Nutr., 59 (21), 3498-3510.

[10] Septiany, G.J., Putri, W.D.R., Panca, N.I., Heriyanto, and Limantara, L., 2019, Carotenoid analysis of ripe banana flesh and peel from three cultivars of banana, Indones. J. Nat. Pigm., 1 (2), 60-64.

[11] Aquino, C.F., Salomão, L.C.C., Pinheiro-Sant'ana, H.M., Ribeiro, S.M.R., De Siqueira, D.L., and Cecon, P.R., 2018, Carotenoids in the pulp and peel of bananas from 15 cultivars in two ripening stages, Rev. Ceres, 65 (3), 217-226.

[12] Khoo, H.E., Ng, H.S., Yap, W.S., Goh, H.J.H., and Yim, H.S., 2019, Nutrients for prevention of macular degeneration and eye-related diseases, Antioxidants, 8 (4), 85.

[13] Valmayor, R.V., Jamaluddin, S.H., Silayoi, B., Kusumo, S., Danh, L.D., Pascua, O.C., and Espino, R.R.C., 2000, Banana cultivar names and synonyms in Southeast Asia, INIBAP Regional Office for Asia and the Pacific, Laguna, Philippines.

[14] Herlina, T., 2007, Peningkatan nilai tambah melalui pengembangan agroindustry pisang di kabupaten Lumajang, Prosiding Seminar Nasional Agroindustri, Bogor, 4 December 2007. 
[15] Hapsari, L., Wahyudi, D., Azrianingsih, R., and Arumingtyas, E.L., 2015, Genome identification of bananas (Musa L.) from East Java Indonesia assessed with PCR-RFLP of the internal transcribed spacers nuclear ribosomal DNA, Int. J. Biosci., 7 (3), 42-52.

[16] Badan Pusat Statistik, 2018, Statistik Tanaman BuahBuahan dan Sayuran Tahunan Indonesia 2018, BPS, Jakarta.

[17] Falcomer, A.L., Riquette, R.F.R., de Lima, B.R., Ginani, V.C., and Zandonadi, R.P., 2019, Health benefits of green banana consumption: A systematic review, Nutrients, 11 (6), 1222.

[18] Hapsari, L., Kennedy, J., Lestari, D.A., Masrum, A., and Lestarini, W., 2017, Ethnobotanical survey of bananas (Musaceae) in six districts of East Java, Indonesia, Biodiversitas, 18 (1), 160-174.

[19] Chandra, R.D., Siswanti, C.A., Prihastyanti, M.N.U., Heriyanto, and Brotosudarmo, T.H.P., 2020, Evaluating pro-vitamin A carotenoids and polar metabolites composition during the ripening stages of Agung Semeru banana (Musa paradisiaca L. AAB), Int. J. Food Sci., 2020, 8503923.

[20] Stover, R.H., and Simmonds, N.W., 1987, Bananas (Tropical Agriculture Series), $3^{\text {rd }}$ Ed., Wiley, Hoboken, US.

[21] Gross, J., 1991, Pigments in Vegetables: Chlorophylls and Carotenoids, Springer US.

[22] Kurniawan, J.M., Yusuf, M.M., Azmi, S.S., Salim, K.P., Prihastyanti, M.N.U., Indrawati, R., Heriyanto, Shioi, Y., Limantara, L., and Brotosudarmo, T.H.P., 2019, Effect of drying treatments on the contents of lutein and zeaxanthin in orange- and yellowcultivars of marigold flowers and its application for lutein ester encapsulation, IOP Conf. Ser.: Mater. Sci. Eng., 509, 012060.

[23] Institute of Medicine (US) Panel in Micronutrients, 2000, Dietary Reference Intakes for Vitamin C, Vitamin E, Selenium, and Carotenoids, National Academies Press, Washington DC.

[24] Mbabazi, R., Harding, R., Khanna, H., Namanya, P., Arinaitwe, G., Tushemereirwe, W., Dale, J., and Paul, J.Y., 2019, Pro-vitamin A carotenoids in East African highland banana and other Musa cultivars grown in Uganda, Food Sci. Nutr., 8 (1), 311-321.

[25] Ekesa, B., Nabuuma, D., Blomme, G., and Van den Bergh, I., 2015, Provitamin A carotenoid content of unripe and ripe banana cultivars for potential adoption in eastern Africa, J. Food Compos. Anal., $43,1-6$

[26] Singh, B., Sing, J.P., Kaur, A., and Sing, N., 2016, Bioactive compounds in banana and their associated health benefits - A review, Food Chem., 206, 1-11.

[27] Ashokkumar, K., Elayabalan, S., Shobana, V.G., Sivakumar, P., and Pandiyan, M., 2018, Nutritional value of cultivars of banana (Musa spp.) and its future products, J. Pharmacogn. Phytochem., 7 (3), 2972-2977.

[28] Buah, S., Mlalazi, B., Khanna, H., Dale, J.L., and Mortimer, C.L., 2016, The quest for golden bananas: Investigating carotenoid regulation in a Fe'i group Musa cultivar, J. Agric. Food Chem., 64 (16), 3176-3185.

[29] Facundo, H.V.V., Gurak, P.D., Mercadente, A.Z., Lajolo, F.M., and Cordenunsi, B.R., 2015, Storage at low temperature differentially affects the colour and carotenoid composition of two cultivars of banana, Food Chem., 170, 102-109.

[30] Yan, L., Fernando, W.M.A.D.B., Brennan, M., Brennan, C.S., Jayasena, V., and Coorey, R., 2016, Effect of extraction method and ripening stage on banana peel pigments, Int. J. Food Sci. Technol., 51 (6), 1449-1456.

[31] Amah, D., Alamu, E., Adesokan, M., van Biljon, A., Maziya-dixon, B., Swennen, R., and Labuschagne, M., 2019, Variability of carotenoids in a Musa germplasm collection and implications for provitamin A biofortification, Food Chem.: X, 2, 100024.

[32] Institute of Medicine (US) Panel in Micronutrients, 2001, Dietary Reference Intakes for Vitamin A, Vitamin K, Arsenic, Boron, Chromium, Copper, Iodine, Iron, Manganese, Molybdenum, Nickel, Silicon, Vanadium, and Zinc, National Academies Press, Washington DC. 